\title{
П.Б. СТРУВЕ ОБ ЭКОНОМИЧЕСКОЙ ЕВРОПЕИЗАЦИИ РОССИИ
}

\begin{abstract}
Аннотация. В статье рассматривается система экономических воззрений П.Б. Струве и в этой связи предложенная им в период увлечения им экономическими идеями Маркса («легальным марксизмом») модель капитализации российской экономики. Идеи этой модели сохранили свою теоретическую и практическую значимость и созвучны сегодняшним проблемам модернизации России.

Ключевъе слова: философия, социальное моделирование, модернизация, хозяйственная система, экономический рост, государственная политика, социальный прогресс, капитализм, народничество, легальный марксизм, консервативный либерализм.
\end{abstract}

Россия из бедной капиталистической страны должна стать богатой капиталистической же страной. Этот исторически необходимый процесс очень труден - в силу нашей культурной и экономической отсталости. П.Б. Струве.

\section{1. Экономические исследования П.Б. Струве}

B отечественной историографии творческое наследие П.Б. Струве до сих пор рассматривается преимущественно в связи с его социально-политическими идеями в рамках интереса к истории отечественного либерализма и прежде всего в том его проявлении, которое вошло в его анналы как консервативный либерализм. Струве был генератором главных его идей, а будучи энциклопедически образованным человеком, всегда активно включённым в политическую жизнь страны, сумел наполнить идеи либерализма глубоким философским смыслом, включить в контекст социального знания (экономики, социологии, политологии, психологии), т.е. концептуально оформить ${ }^{1}$. Сегодня, как отмечают исследователи, идеи консервативного ли-

\footnotetext{
${ }^{1}$ Не случайно и справедливо во всех энциклопедических изданиях П.Б. Струве характеризуется, как «политик, публицист, издатель, историк, экономист (курсив - И.С.) и философ».
}

берализма предвосхитили многие подходы современных аналитиков к оценке роли либерализма в жизни модернизирующегося общества, в решении жизненно важной для него проблемы: как соединить экономический либерализм с духовно-культурным консерватизмом и сильным государством. Но при всём интересе к творческому наследию Струве до сегодняшнего дня без должного внимания остаются его экономические идеи и прежде всего системное исследование экономического состояния России конца XIX века - «Критические заметки к вопросу об экономическом развитии России» ${ }^{2}$. Работа была опубликована в 1894 году на заре его юношеских увлечений, как тогда называли, «экономическим материализмом». Важно заметить, что эта работа не стала его единственным исследованием по экономике. Интерес к экономической проблематике и экономической истории России Струве сохранит надолго, свидетельством чего являются его магистерское исследования «Хозяйство и цена. Критические исследования по теории и истории хозяйственной жизни». Ч. 1. (М., 1913), ч. 2 (М., 1916) и работа «Понятие и проблема капитала в системе политической экономии, построенной на понятии цены» (М., 1917). (В этом же 1917 году Струве был избран членом Академии

\footnotetext{
${ }^{2}$ Исключением является исследование О.Л. Гнатюка «П.Б. Струве как социальный мыслитель» (СПб, 1998). См. главу «Социально-философские воззрения: от критического марксизма и «критического позитивизма» - к научно-критической метафизике». С. 16-60.
} 


\section{Философия и культура 4(64) • 2013}

наук по отделению политической экономии). К сожалению, ни первая книга, ни две последующие работы при массовой републикации его статей в последние двадцать лет до сих пор не переизданы ${ }^{3}$. Наконец, говоря о Струве как экономисте следует назвать труд, над которым он работал долгие годы - «Социальная и экономическая история России с древнейших времён до нашего, в связи с развитием русской культуры и ростом российской государственности» (Париж, 1952; М., 2010)4 .

«Критические заметки к вопросу об экономическом развитии России» - это первая попытка социального моделирования развития (модернизации) России, ориентированная на практические нужды страны с учётом её национальной истории, сложившихся культурных традиций и новейших тенденций промышленного развития Запада. Обращение к этому проекту сегодня не должно вызывать удивления из-за факта его давности - он не имеет значения потому, что начало XXI века, в котором мы живём, и конец XIX века по странной иронии отечественной истории «упираются» в одну проблемную ситуацию: вхождение страны в капитализм.

Общий смысл модернизации для России Струве сформулировал предельно чётко: как порвать с «азиатчиной» и превратить страну в богатую капиталистическую державу. Он обозначил две составляющие такого превращения: экономический рост и вхождение в мировое сообщество на правах цзивилизованного государства. Предлагаемые для этого средства, как и сама задача, сегодня не утратили своей практической значимости: «нервным центром» проекта была актуальная в наши дни проблема ответственной свободы лица и исповедующей демократические принциипь

\footnotetext{
3 «Критические заметки к вопросу об экономическом развитии России» есть в формате ПДФ. Книга появились в 2011 г. на сайте электронной библиотеки «Университетская библиотека», а так же: www knigafund.ru/books/. Что касается самого оригинала, как и сборника «На разные темы» (СПб., 1902) с включённой в него статьё «Моим критикам» (ответ на замечания по поводу «Критических заметок к вопросу об экономическом развитии России»), то оно отнесено к антикварному изданию. И вообще о первом исследовании Струве, благодаря которому он стал широко известным, мы сегодня по-прежнему больше знаем по критике его Лениным.

${ }^{4}$ Отечественное переиздание см.: Струве П.Б. Избранные труды. М.: Росспэн, 2010. Сам Струве успел подготовить к печати лишь первую часть труда, вторая часть была обнаружена в черновом варианте в его архиве. В конце 40-х годов его сыновья начали подготовку её к печати, и в доработанном виде она вошла в названное издание.
}

власти. От решения этой задачи зависит, как был уверен Струве, и в чём мы сегодня убеждаемся на собственном опыте, общий успех и культурная наполненность модернизационных преобразований, которая является сущностной чертой модернизации, если она реализуется как многофакторный социокультурный процесс. За последним всегда стоят соответствующие мироощущение и мировоззрение человека, его понимание окружающего мира и своего места в нём, мотивация и стиль поведения, усвоенная система ценностных ориентаций и культурных предпочтений, наконец, общественные, в том числе политические, формы жизни, определённая система прав и обязанностей государства и граждан. В этом смысле, думаю, можно сказать, что Модернизация есть Реформация, охватывающая в наше время, в отличие от её более ранних исторических проявлений, и материальную, и духовную жизнь людей в ихединстве. Проект Струве исходит именно из такого её понимания, к сожалению, в наши дни далеко не всегда принимаемого к практической реализации. В 1901 году Струве дал такую характеристику своей книги: «Я считаю до сих пор верными взгляды на экономическое развитие России, высказанные в 1894 году. Мне кажется, что именно эти взгляды, чуждые крайностей как ортодоксального марксизма, так тем более народничества, в полемике с которыми они были высказаны, вполне уже в значительной степени вошли в общее сознание $<\ldots>$. Случилось, что эти взгляды имели за собой сильную союзницу - силу вещей и жизни» 5 . Как это ни покажется странным, «сила вещей и жизни», стоявшая в своё время за проектом Струве, мало в чём претерпела изменения сегодня. И мне представляется, что идеи книги, во многом, как я постараюсь показать, созвучные современным проблемам модернизации, делают стоящий за ними консервативно-либеральный Проект преобразований востребованным.

И ещё один момент, на который следует обратить внимание. С изданием «Критических заметок к вопросу об экономическом развитии России» связывают начало своеобразного общественного движения - «легального марксизма». Его идеи во многом определили содержание, критическую направленность и научный аппарат книги, а сама книга поставила её автора во главу этого движения, но и в рамках, если можно упо-

\footnotetext{
${ }^{5}$ Струве П.Б. На разные темы (1893-1901 гг.). Сборник статей. СПб., 1902. С. 303.
} 


\section{Социальная динамика}

требить это слово применительно к Струве, всегда пытавшемуся выйти за любые рамки, он оставался на тех позициях, которые выражали его личные убеждения. «Примыкая по некоторым основным вопросам к совершенно определившимся в литературе взглядам, он /автор/, нисколько не считал себя связанным буквой и кодексом какой-нибудь доктрины, - предупреждал он в Предисловии к книге. - Ортодоксией он не заражён, если только под ортодоксией не разуметь стремление к последовательному мышлению» ${ }^{6}$.

\section{2. Струве и «легалънъй марксизм»}

Начало 90-х годов XIX века было переломным временем в развитии российской общественной мысли. И как всегда бывает в такое время, палитра общественно-философских направлений была многокрасочной.

Содной стороны, находили свою нишу буквально все течения, сформировавшиеся в предшествующее десятилетие: по-прежнему, хотя и в несколько смягчённой форме, продолжали спорить о путях развития России славянофилы и западники; получив новых союзников и новых противников, оставались «в силе» все направления либерализма от классического, «охранительного» (Б.Н. Чичерин, П.И. Новгородцев) до нового, «социального» (Б.А. Кистяковский, С.А. Котляревский); немало приверженцев имели идеи М.А. Бакунина и П.А. Кропоткина; сформировалась самостоятельная социологическая школа - в философии, истории, психологии (Н.И. Кареев, В.О. Ключевский, М.М. Ковалевский, Р. Виппер, Де-Роберти); окончательно утвердилась в разночинно-интеллигентской среде идеология народничества (П.Л. Лавров, Н.К. Михайловский, В.П. Воронцов); уже создал свою «теократию» Вл. Соловьёв, положив начало новым религиозным изысканиям; становился широко известным марксизм.

Духовными скрепами общественной мысли выступали прежние ценности, делавшие российскую духовную культуру самобытной и одновременно похожей на европейскую, вернее, соравной ей. Такими скрепами оставались ориентация на гуманизм, интерес к теме человека и его судьбе, доминирование в общественной мысли моральных установок и этических схем жизни, исповедание своеобразной «мы-философии», связывающей

\footnotetext{
${ }^{6}$ Струве Пётр. Критические заметки к вопросу об экономи-
} ческом развитии России. СПб., 1894. С. VII. самореализацию личности прежде всего с общением и коммуникаторными (Бердяев) формами жизни, вера в жизненную силу нравственных принципов мироздания, в призвание человека к постижению их с тем, чтобы преобразовать мир на началах добра. Но главное, каждому из направлений было свойственно неприятие социальной несправедливости, сострадательность к униженным и оскорблённым, протест против жестокости тех условий, в которых жил народ. Всех объединяло активное переживание настоящего и будущего России, перспектив её экономического, социального и духовного развития. Перефразируя известное изречение Герцена, можно сказать: Все были разные, но сердце у всех билось одно.

C другой стороны, несмотря на плюрализм теорий, парадигм и интерпретаций существующей ситуации, чувствовалась тяга к оценкам более однозначным, потребность в теории, которая решилась бы взять на себя ответственность за рекомендации «что делать». Иными словами, общественно-философская мысль словно замерла в ожидании чего-то нового, способного вывести из состояния неопределённости и приоткрыть дверь в будущее, увидеть его, пусть и смутные, контуры. Осозналась потребность в теории, которая стала бы «руководством к действию», которую можно было бы принять, пусть и ценой утраты каких-то старых истин. Случилось так, что эту роль в социалдемократической среде 90-х годов прочно связали c «экономическим материализмом» Маркса, с его идеей о доминировании экономического фактора в общественном развитии.

Идеи марксизма (термин, вошедший в научный оборот позже) стали известны гораздо раньше. Начиная с 40-х годов вели переписку с Марксом и Энгельсом П.В. Анненков, П.Л. Лавров, Н.Ф. Даниельсон, Г.А. Лопатин, позже - П.Н. Ткачёв, В.И. Засулич, В.В. Берви-Флеровскийт. В 1861 году журнал «Современник» опубликовал изложение Н.В. Шелгуновым работы Энгельса «Положение рабочего класса в Англии», в 1865 году в пересказе П.Н. Ткачёва появилось Введение из «К критике политической экономии» Маркса, в 1869 году был издан на русском языке «Манифест коммунистической партии», чуть позже, в 1872 году - I том «Капитала» в переводе Г.А. Лопатина и Н.Ф. Даниельсона; в 1894 году вышел русский перевод книги Энгельса

\footnotetext{
7 Сохранилось 147 писем Маркса и Энгельса русским корреспондентам и 312 писем отечественных деятелей общественных движений. См.: Аникин А.В. Путь исканий. М., 1990. С. 382.
} 


\section{Философия и культура 4(64) • 2013}

«Происхождение семьи, частной собственности и государства». Русская интеллигенция в 70-90-е годы активно читала доступные ей работы Маркса, идеи которого становились всё более популярными. Появились активные последователи и пропагандисты экономического учения Маркса из среды профессиональных экономистов, среди которых наибольшее влияние имели И.И. Кауфман, Н.И. Зибер, М.И. Туган-Барановский, выступившие с серией статей на страницах легальной печати. Так, Зибером, профессором киевского университета, был опубликован ряд статей под общим названием «Экономическая теория К. Маркса ${ }^{8}$, вышли работы А.И.Скворцова «Влияние парового транспорта на сельское хозяйство» (1890) и «Экономические этюды»(1893), оказавшие большое влияние на приверженцев нового направления 9 .

Следует однако сказать, что популярность марксистских идей, как справедливо заметил К.М. Кантор, имела и обратную сторону ${ }^{10}$. Пересказы, интерпретации, да и сами переводы не всегда адекватно отражали пропагандируемые идеи, а сами они не давали систематического представления о марксизме как философском учении, не говоря уже о том, что пересказы несли на себе печать идей самих интерпретаторов и того контекста, в который включались не редко волей случая. В этой связи уместно вспомнить слова самого Маркса: «Такова ирония судьбы, - писал он, - русские, с которыми я в течение 25 лет беспрерывно боролся в своих выступлениях, не только на немецком, но и на французском и на английском языках, всегда были моими «благодетелями». В 1843-1844 гг. в Париже тамошние русские аристократы носили меня на руках. Моё сочинение против Прудона (1847), а также то, что издал Дункер (1859, «К критике политической экономии») нигде не нашли такого большого сбыта, как в России. И первой иностранной нацией, которая переводит «Капитал», оказывается русская. Но всё это не следует

\footnotetext{
8 Позже эти статьи в переработанном виде были переизданы в 1895 г. под общим названием «Давид Рикардо и Карл Маркс в их общественно-экономических исследованиях».

9 Струве писал, вспоминая это время: «Мы (я и Скворцов, мой «легальный марксизм») <...> восприняли идею, когдато применённую Марксом к Германии, а именно - что мы страдаем не от развития капитализма, а от недостаточного его развития». (Струве П.Б. Мои встречи и столкновения с Лениным // Русская идея. В кругу писателей русского зарубежья. Т. 1. М., 1994. С. 392).

10 См.: Кантор К.М. Немецкая идеология Маркса-Энгельса и русский марксизм // Вопросы философии. 1995. № 12.
}

переоценивать. Русские аристократы в юношеские годы воспитываются в немецких университетах и в Париже. Они всегда гонятся за самым крайним, что даёт Запад. Это чистейшее гурманство, такое же, каким занималась часть французской аристократии в XVIII столетии» ${ }^{11}$. Можно не соглашаться со столь нелестной оценкой «русских аристократов», но, ведь, классик не мог даже предположить, какую роль станет играть его учение в жизни нескольких поколений русских в недалёком будущем. Справедливости ради следует заметить, что подобной оценки придерживались и многие из тех «русских аристократов», кто воспринял учение Маркса как теорию, открытую для критики, и в свою очередь предостерегал от неудачных её популяризаций. Так, Струве в 1894 г. писал: «Относительно Маркса и в частности применительно к России можно сказать: нигде идеи Маркса не были так быстро реципицированы как в России, не только публицистически, но и так называемым научным образом (Н.И. Зибер), но нигде, быть может, не приходится наталкиваться на такое понимание Маркса, как у русских публицистов» ${ }^{12}$. И предостерегая от возможных упрощений учения Маркса, предупреждал: «неужели выяснением генезиса капиталистического строя исчерпывается историко-философское учение Маркса? Нет, ибо в таком случае она была бы не историко-философская теория, а именно только выражение причинных связей, существующих между разными сторонами данного исторического процесса» ${ }^{13}$.

Популярность марксизма в 90-е годы объяснялась в первую очередь возможностью дать с его позиций критику зашедшей в тупик идеологии народничества с её абсолютизацией субъективного метода в социологии и интерпретацией возможностей модернизации отечественной экономики в духе идей славянофильства. Марксизм в России на рубеже веков, отмечал С.Л. Франк, был реакцией прежде всего на славянофильские ориентации народничества, связанные с обоснованием им особого, русского, пути к социализму. Это наложило свой отпечаток на "русский марксизм», определив его проблематику и идеологические предпочтения. А.А. Кизеветтер много позже вспоминал: «То была пора бесконечных ожесточённых полемических турниров между «народниками» и

\footnotetext{
11 Маркс К., Энгельс Ф. Соч. Т. 32. С. 472.

12 Струве П.Б. Критические заметки к вопросу об экономическом развитии России. СПб., 1894. С. 43.

13 Там же. С. 45.
} 


\section{Социальная динамика}

«марксистами». Со времени знаменитых споров между западниками и славянофилами русское общество ещё не переживало такого острого параксизма идеологической борьбы. Но если полемика между западниками и славянофилами велась в своё время в четырёх стенах некоторых салонов, в среде избранных кружков передовых мыслителей, то споры между марксистами и народникам в 90-х годах захватили самые широкие круги и одно время, можно сказать, почти всецело наполнили собой содержание умственных интересов русского общества. <...> Куда бы вы ни появились, вам прежде всего предлагали вопрос: вы марксист или народник?» ${ }^{14}$.

Марксизм был воспринят, как «свежий ветер с запада» (Франк), как последнее слово европейской науки. «После политического удушья 80-х годов, писал С.Н. Булгаков, - марксизм является источником бодрости, деятельного оптимизма, боевым кличем молодой России, как бы общественным бодрилом, он усвоил и настойчиво пропагандировал определённый, освящённый вековым опытом Запада практический способ действия, а вместе с тем он оживил упавшую было в русском обществе веру в молодость национального возрождения, указывая в экономической европеизации России верный путь к этому возрождению» ${ }^{15}$. В марксизме увидели учение, которое давало ответ на вопрос, как России приобщиться к достижениям мировой цивилизации, в нём «казалась преодолённой та пропасть, тот дуализм между общефилософским мировоззрением и областью социального развития, который составлял слабую сторону народников» ${ }^{16}$. Вот почему в 90-х годах в марксизме получили «крещение» (Федотов) все новые, в том числе консервативные, направления русской политической мысли.

Но по этой же причине «русский марксизм» существовал во множестве различных версий. Особой его разновидностью и стал «легальный марксизм», акцентировавший внимание в первую очередь на политэкономических идеях Маркса применительно к двум болезненным проблемам российского развития: 1) как расширить рамки гражданской свободы и 2) как поднять экономическую жизнь страны на

${ }^{14}$ Кизеветтер А.А. На рубеже двух столетий. Прага, 1929. C. 211-212.

15 Булгаков С.Н. От марксизма к идеализму. Сборник статей (1896-1903). СПб, 1904. С. VII.

16 Левицкий С.А. Очерки по истории русской философии. T. 2. M., 1996. C. 242. более высокий уровень. Представителями этого направления (П.Б. Струве, М.И. Туган-Барановский, С.Н. Булгаков, Н.А. Бердяев) учение Маркса отождествлялось не с научным социализмом (идеями классовой борьбы как движущей силы истории, пролетарской революции и диктатуры пролетариата), а с его экономическим учением о капитализме, в котором видели обоснование исторической необходимости модернизации России, её движения по пути капитализма. Идеи Маркса увязывались с чисто либеральными задачами, что придавало им «смягчённый характер». Можно сказать, что сторонниками «либерального марксизма» была сделана первая попытка либерализации марксизма, которую позже Струве, характеризуя собственное мировоззрение, назовёт критическим марксизмом, и из которого ещё позже «выйдет» консервативный либерализм. Вехами на этом пути станут для него работы «Свобода и необходимость» (1897), «Против ортодоксальной нетерпимости - pro doma sua» (1901), Предисловие к книге Н.А. Бердяева «Субъективизм и индивидуализм в общественной философии» (1901), сборник статей «На разные темы (1893-1901)» (1902).

«Легальный марксизм» предстал как своеобразный сплав западничества с традициями отечественной общественно-философской мысли, «заразив» здравостью (а не революционностью!) своих идей значительную часть российской интеллигенции. Несмотря на недолгое увлечении его идеями, последние оказали существенное влияние на последующее развитие отечественной экономической, политической и философской мысли, определив её точки роста в новом столетии. Н.А. Бердяев, вспоминал, что «марксистское течение $<. . .>$ стояло на гораздо более высоком культурном уровне, чем другие течения революционной интеллигенции. Это был тип мало похожий на тот, из которого впоследствии вышел большевизм. Я стал критическим марксистом, и это дало мне возможность остаться идеалистом в философии. Произошла дифференциация разных сфер и освобождение сознания, сферы духовной культуры. Марксизм того времени этому способствовал <...> Марксизм конца 90-х годов был несомненно процессом европеизации русской интеллигенции, приобщением её к западным течениям, выходом на большой простор» ${ }^{17}$. Близким к такой оценке было восприятие нового направления Г.П. Фло-

\footnotetext{
17 Бердяев Н.А. Самопознание. Опыт автобиографии. Париж, 1949. С. 125.
} 


\section{Философия и культура 4(64) • 2013}

ровским: «Для 90-х гг. характерны неокантианские мотивы, идеология императивов и долга, пафоса морального благородства <...> Антитезой этому моралистическому мировоззрению был марксизм <..> Марксизм был практически возвращением к онтологии, к действительности, к «бытию» ${ }^{18}$.

Итак, «легальный марксизм» возник (и был воспринят интеллигенцией) как ответ на вопрос о путях модернизации России, как искомое обоснование в рамках социал-демократического мировоззрения перехода страны на капиталистический путь развития, позволявшее подвести черту под утомившим всех спором с народниками о будущем страны. В этом качестве он заявил о себе в полный голос книгой Струве «Критические заметки к вопросу об экономическом развитии России». Но надо сказать, что первый ощутимый удар по народничеству Струве нанёс годом раньше серией рецензий на книгу Н.Ф. Даниельсона «Очерки нашего пореформенного хозяйства» (1893) и работы В.П. Воронцова. Эти статьи можно считать подготовительным материалом книги: уже в них Струве высказал мысль, что капитализму в России принадлежит «большое будущее и важная историческая миссия». В 1894 году, предлагая свою модель модернизации российского общества, Струве даёт обоснованную, конкретизируемую научным анализом российской экономики и европейского опыта капиталистического развития, критику теории «самобытного экономического развития России». Своей книгой он, с одной стороны, нарушил монополию народников на социологическое осмысление российских экономических реалий, отнеся их «к категории устаревших шляпок», с другой стороны, их взглядам противопоставил новую теорию развития народного хозяйства.

Одновременно со Струве против признанных теоретиков народничества выступили М.И. Туган-Барановский («Промышленные кризисы в современной Англии», 1894, статьи в журналах «Мир Божий», «Новое слово») и В.И. Ленин («Что такое друзья народа и как они воюют против социал-демократов», 1894), но работа Ленина осталась менее известной, поскольку была издана маленьким тиражом на гектографе. Всем троим вместе было столько лет, сколько метру народников

18 Флоровский Г.П. Пути русского богословия. Вильнюс, 1991. С. 559.
Н.К. Михайловскому ${ }^{19}$. На этом этапе «легальный марксизм» не афишировал своё несогласие с «ортодоксами», школой Г.В. Плеханова ${ }^{20}$. Их объединяла борьба с общим врагом - самодержавием и неприятие народнической идеологии, общее понимание, что продуктивная критика последней возможна только с позиций марксова учения об общественном развитии и капитализме как закономерном историческом этапе (общественно-экономической формации) человеческой цивилизации.

И вместе с тем, следует признать, что именно книга Струве стала первым опытом критики многих идей марксизма ${ }^{21}$. Не случайно термин «легальный марксизм», с которым общественное мнение связывало работу Струве, сам он считал неудачным, «внушающим неправильные ассоциации и возбуждающим недоразумения своим наименованием», и полагал более подходящим для характеристики своих взглядов определение «критическое движение в марксизме» ${ }^{22}$. В 1901 году он писал: «главной задачей «Критических заметок» была полемика с народническим пониманием экономического и общественного развития России и этот антинароднический характер моей первой литературной попытки в значительной мере скрадывал от материалистических противников мою неортодоксальность, а ортодоксальных марксистов с нею до известной степени примирял.

\footnotetext{
19 Вопрос об интерпретации экономических идей ТуганомБарановским требует отдельного рассмотрения. Дело в том, что с самого начала в его варианте марксизма особо зазвучал тезис о роли в общественном развитии этического начала. Развивая эту идею, он обвинит марксизм в расплывчатости определения понятия «хозяйство», не учитывающего, по его мнению, двух его главных измерений: 1) хозяйство есть всегда средство, а не цель и 2) хозяйство направлено не на человека, а на производство материальных условий его жизни.

20 Можно вспомнить следующее свидетельство этому: именно к Струве в 1898 г. обратился Петербургский «Союз борьбы» с предложением написать текст «Манифеста российской социал-демократической партии», что он и сделал, выдержав ортодоксальную концепцию, хотя, как признавал позже, его взгляды были более сложными, а в 1900 г. Струве и Туган-Барановский на совещании в Пскове заявили о своём намерении поддержать издание газеты «Искра», несмотря на нескрываемое несогласие с её общим ортодоксально-марксистским направлением.

21 Это предмет отдельного разговора, и в рамках выбранного аспекта рассмотрения темы я этой проблемы касаться детально не буду.

22 Струве полагал, что элемент критики в русском марксизме гораздо сильнее, чем в западноевропейском, что ему
} свойственна большая решительность. 


\section{Социальная динамика}

В то же время я и разумом и чувством понимал тогда, что прежде всего необходимо вести и покончить союзную борьбу против народничества и подготовлять новое практическое и действенное понимание русской действительности. И не будучи никогда ортодоксом, я чувствовал себя в этих двух задачах вполне солидарным с ортодоксией. В это время <...> мне казалось преждевременным резко выдвигать и развивать критические сомнения тем более, что они во мне самом ещё не утвердились в достаточной мере» ${ }^{23}$. Примечательна реакция на эту книгу Г.В. Плеханова в том же 1894 году. В Приложении своей работы «К вопросу о развитии монистического взгляда на историю - ответ Михайловскому, Карееву. В.В. и К.» он, уделив Струве две страницы, лишь посетовал на то, что тот слишком неосторожно выразился (речь шла о нашумевшем призыве идти на выучку к капитализму), объясняя это «благородным увлечением западника», и полагал, что шуметь по поводу книги позволительно только тому, кому нечего возразить на экономические доводы писателя ${ }^{24}$. Позже в 1901 году в работе «Критика наших критиков - г. Струве в роли критика марксовой теории общественного развития» он обвинит Струве и всех «легальных марксистов» в попытках реформировать марксово учение об общественном развитии. Та «европеизация» русской общественной мысли, которую он приветствовал в критике народничества, не оправдала, по его оценке, надежд, поскольку осуществилась «в неожиданной форме», а именно «под знаменем пересмотра марксизма» ${ }^{25}$. Но время больших споров и конфронтации было ещё впереди. А сближение, хотя и эфемерное, было на тот период (начало 9о-х годов) значимым для обеих сторон. Когда народничество утратит свою силу, ослабит свои позиции, Струве не будет считать ни нужным, ни возможным воздерживаться от критики «ортодоксов», полагая, что «право критики есть одно из драгоценнейших прав живой мыслящей личности».

\footnotetext{
${ }^{23}$ Струве П.Б. Моим критикам // Струве П.Б. На разные темы (1893-1901 гг.). Сборник статей. СПб., 1902. С. 3.

${ }^{24}$ См.: Плеханов Г.В. Избранные философские произведения. Т. 1. М., 1965. Впрочем, такой «мягкой» оценке есть своё объяснение: в это время Струве был близок своими идеями Плеханову, считавшему, что «за капитализмом вся динамика нашей общественной жизни, что Россия пока «не испекла той муки, из которой можно испечь пирог социализма».

25 Плеханов Г.В. Избранные философские произведения. М., 1965. T. 2. C. 630.
}

Но даже много лет спустя, окончательно порвав с марксизмом и став политическим противником большевиков, Струве никогда не сожалел о своём «юношеском увлечении» и отмечал, что стал марксистом, осознав научное значение экономического учения Маркса для выработки путей модернизации, преодоления экономической и культурной отсталости России ${ }^{26}$.

Начало XX века стало переломным моментом для «легального марксизма»: от него отходят почти все его сторонники. Своеобразным манифестом его коллективного преодоления стал сборник статей под ред. П.И. Новгородцева «Проблемы идеализма» (1902), в котором выступили Струве, Бердяев, Булгаков, вскоре составившие вместе с Франком ядро направления, соединившего философию идеализма с либеральными ориентациями российской интеллигенции. Для адекватной оценки роли «легального марксизма» в интеллектуальной жизни России конца XIX века важно понять, что и увлечение марксизмом, и отказ от него были связаны для представителей этого направления с мучительными философскими исканиями, что «легальный марксизм» был отражением тех глубинных процессов, которые происходили не только в интеллектуальной, а во всех сферах жизни российского общества. Он был своеобразным «знаком» своего времени, - времени, соединившем стремление к материализму, к бытию со страстными порывами духа к идеальному.

\section{3. Модель европеизации российской экономики}

«Критические заметки к вопросу об экономическом развитии России» своей первой целью имели критику народнической теории самобытного развития России. Своим исследованием, как справедливо отмечает П.Б. Гнатюк, Струве подвёл черту под застаревшим спором между «чистыми западниками» - их «индивидуализмом» и «рационализмом» - и славянофилами с их мечтаниями об оригинальной русской или

\footnotetext{
26 Туган-Барановский, одновременно со Струве выступивший с критикой народничества с позиций экономического учение Маркса, отойдя от «легального марксизма», скажет так: «Я избегал называть себя марксистом, но общественное мнение признало меня таковым, и я не протестовал против этого». (См.: Туган-Барановский М.И. Очерки новейшей политической экономии. СПб, 1903. С. V). У каждого был свой путь к марксизму и свой путь отхода от него.
} 


\section{Философия и культура 4(64) • 2013}

славянской духовно-общественной культуре» ${ }^{27}$. Предмет спора был фактически «снят», потому что была предложена совсем иная экономическая модель развития страны, обоснование и конкретизация которой определила вторую цель книги. Эта модель ориентировала на принятие европейского, т.е. капиталистического, пути развития как адекватного ожидаемым трансформациям в российской экономике, государственном устройстве, культуре. И хотя до Струве «были русские авторы, отмечавшие при случае цивилизаторскую роль капитализма, например, Белинский, Петрашевский, Писарев, ни один русский мыслитель до него не приписывал капитализму столь жизненно важной исторической миссии ${ }^{28}$.

В качестве методологии исследования и социального прогнозирования Струве предложил марксово учение о роли экономического фактора (способа производства и форм обмена) в жизни и развитии любого общества, - учение, воспринятое им в качестве научной теории и эвристического принципа, указывающего «подобно ариадновой нити, куда преимущественно следует направлять исследователю общественных явлений своё внимание» ${ }^{29}$. Утопизму народнической модели была противопоставлена основанная на экономическом анализе модель трансформации хозяйственной структуры общества, отвечающая «европейским стандартам».

Струве видел, что натуральное хозяйство пережило себя исторически, что оно стихийно вытесняется меновым хозяйством в силу его экономической и культурной несостоятельности. Народническая «идиллия «земледельческого государства» и «народного производства», т.е. натурального хозяйства, разрушалась «под свист локомотива». При этом «роль парового транспорта, - убеждал Струве, - не ограничивается областью экономических отношений: его влияние охватывает всю жизнь общества и производит в ней глубокий переворот. Благодаря паровому двигателю возникает мировое хозяйство, благодаря ему создаётся действительно социальный строй и отдельные хозяйства связываются крепкой ор-

\footnotetext{
27 Гнатюк О. П.Б. Струве как социальный мыслитель. СПб., 1998. C. 32.

28 Пайпс Р. Теория капиталистического развития П.Б. Струве. СПб, 2012. С. 287.

29 Струве П.Б. На разные темы (1893-1901 гг.). Сборник статей. СПб, 1902. С. 301.
}

ганической связью»3º. (На память приходят слова другого мыслителя, который, напомню, писал, что династия Габсбургов выдержала Французскую революцию 1848-1850 годов, но пара она выдержать не сможет.) Революционизирующее воздействие технического прогресса на развитие всей системы общественных отношений Струве признавал полностью, но не безусловно: значение первого, считал он, есть необходимое, но недостаточное условие второго. - Модернизация (капитализация) мыслилась Струве как процесс, охватывающий все сферы российского общества, более того, рост производительности труда, структурные и технико-организационные изменения в общественном производстве (материальная база модернизационных преобразований) увязывались с развитием правовых основ государства, демократизацией его институтов и принципов общественной жизни на всех её уровнях, с ростом уровня профессиональной образованности (дисциплины труда) и общей культуры населения на «почвенном материале». (Именно эта идея позже стала главной в его концепции «Великая Россия»).

Модель Струве предупреждала, с одной стороны, о недопустимости отставания экономических реформ от социально-политических преобразований, а с другой стороны, от преждевременного разрушения исторически сложившихся государственных структур и образа жизни страны, от крайностей разных вариантов левого и правого радикализма, дабы, избежав социального хаоса, защитить автономию человеческой личности, её право на самовыражение, - защитить «право лица». Важно заметить, что в «Критических заметках к вопросу об экономическом развитии России» Струве говорил не о программе партии , как это станет позже, а о предпочтительном для России типе социально-экономического развития, что освобождало предложенную им модель модернизации от каких бы то ни было идеологических предвзятостей.

Какие идеи определили смысл предложенного Проекта капитализации России?

Первая идея. Прогресс экономики есть необходимое условие социального прогресса, последний «исторически вытекает из первого и на известной ступени развития между обоими процессами должно являться и на самом деле является органическое

\footnotetext{
${ }^{30}$ Струве П.Б. Критические заметки к вопросу об экономическом развитии России. СПб, 1894. С. 114.
} 


\section{Социальная динамика}

взаимодействие, взаимная обусловленность» ${ }^{31}$. Поэтому вопрос об организации производства и росте производительности труда есть «первенствующий» перед вопросом о распределении, на котором «споткнулись» народники, строя свою модель развития страны и достижение социалистического идеала. Последнее, если возможно, то лишь через прохождение этапа капитализма, для которого важно «платящее потребление, а не потребление вообще» 32 .

Вторая идея. Капитализм есть необходимая фаза цивилизационного развития, современная культура выросла вместе с ним или на его почве. Его историческая миссия заключается в создании материальных и интеллектуальных условий для дальнейшего продвижения человечества по пути прогресса. Фазы последнего органично, множеством объективных факторов, «родственных нитей» связаны друг с другом, но являются самодостаточными, поэтому их нельзя произвольно «перескочить». А «социальные реформы составляют звенья, связующие капитализм с тем строем, который его сменит и - каков бы ни был политический характер того заключительного звена, которое явится гранью между двумя общественно-экономическими формами - одна форма исторически вырастет из другой» 33 .

Третья идея. Объективное (социально-экономическое) основание капитализма есть товарное производство, которое «обобществляет не только производство, но и производителя, оно делает человека настоящим социальным существом, связывая индивидуальное существование тысячью нитей со всем общественным организмом» 34 . Товарное производство предполагает существование правовых институтов, а соответственно определённые правопорядок и правосознание. Иными словами, «товарное производство является могущественным культурным фактором. Раз страна стала на путь его развития, весь культурный, политический и экономический прогресс зависит от дельнейших успехов на этом пути» 35 .

Четвёртая идея. Для страны, в которой превалирующим является сельское хозяйство, какой была

\footnotetext{
31 Там же. С.133

32 Струве П.Б. Моим критикам // Струве П.Б. На разные темы (1893-1901 гг.). Сборник статей. СПб., 1902. С. 53.

33 Струве П.Б. Критические заметки к вопросу об экономическом развитии России. СПб., 1894. С. 130.

34 Там же. С. 160.

35 Там же. С. 283.
}

Россия в 90-х годах, социально-экономический прогресс связан с развитием земледелия на основе товарного обмена и обрабатывающей промышленности. Превращение сельскохозяйственного производителя в товаровладельца, вовлечение его в товарное обращение придаёт мелкому земледельческому хозяйству жизненные силы, а обрабатывающая промышленность делает его соответствующим общим требованиям экономической и технической рациональности. Рынок, превращает земледельца в производителя товара, а развитие обрабатывающей промышленности делает реальной замену натурального хозяйства рациональным хозяйством, основанным на применении передовой техники, технологии и организации труда.

Пятая идея. Движение по пути капитализации предполагает возрастание роли государства, осуществляющего социальную политику на основе идеи права. В регулировании модернизационных процессов и в снятии социальной напряжённости, неизбежно сопровождающей вызванный капитализацией рост экономического расслоения общества, политика государства должна по возможности выражать равнодействующую общественных сил. Но перед многими явлениями социальноэкономического неравенства государство может оказаться бессильным в своих попытках следовать такой политике.

Шестая идея. Хозяйственная система не есть нечто мёртвое, лишённое духовности, её обязательным элементом является человеческая личность, отмеченная духовно-нравственными свойствами (добросовестность, ответственность, расчётливость, профессионализм, культурность), отвечающими осуществляемым трансформациям. Более производительная хозяйственная система опирается на более высокую «личную годность», а прогрессирующее, т.е. модернизирующееся, общество возможно только при условии «личной годности» его субъектов, как «основе и мериле всех общественных отношений». «Личная годность» (в хозяйственной деятельности, в искусстве, в политике) - это необходимое условие успешности любых модернизационных преобразований. Обосновывая этот тезис позже в статье «Интеллигенция и народное хозяйство», Струве скажет: «я повторяю то, на чём настаивал около 15 лет тому назад в своих «Критических заметках» ${ }^{36}$, и с с го-

\footnotetext{
${ }^{36}$ Струве П.Б. Интеллигенция и народное хозяйство // Струве П.Б. РATRIOTIK. Политика, культура, религия, социализм. M., 1997. C. 204.
} 


\section{Философия и культура 4(64) • 2013}

речью заметит, что в русской революции идея личной годности была совершенно погашена. - «Она было утоплена в идее равенства безответственных личностей» 37 .

Седьмая идея. Развитие страны должно быть признано на уровне общественного и индивидуального сознания как национальный идеал и национальное служение. В этом смысле модернизация, если она ориентирована на прогрессирующее развитие страны, всегда реализуется как национальная идея.

Итак, для сельскохозяйственной страны, какой было Россия 90-х годов, деревня, которая при этом продолжала жить по законам натурального хозяйства, движение по пути социально-экономического прогресса, в соответствии с предлагаемой Струве моделью, связано с развитием земледелия на основе товарного обмена. Только такой путь превратит мелкое земледельческое хозяйство в жизнеспособное, т.е. удовлетворяющее «общим требованиям экономической и технической рациональности» ${ }^{38}$. Крестьянина необходимо сделать товарным производителем - это главное условие роста производительности его труда и укрепления экономической самостоятельности. И даже несколько лет спустя Струве считал, что для России «первичным моментом является не развитие промышленного капитализма на почве насильственной экспроприации непосредственного производителя , а вовлечение земледелия в обмен, дифференцирующее сельское население на класс сельской более-менее мелкой буржуазии и сельский пролетариат, из которого рекрутируется и пролетариат промышленный» 39 . Возражая народникам, сетовавшим на то, что капитализация крестьянского хозяйства в России невозможна из-за отсутствия развитого внутреннего рынка (а отсюда - упование народников на «особый путь через усиление натурального хозяйства»), Струве утверждал, что разорвать эту зависимость можно только одним способом - вытеснением натурального хозяйства, основанного на примитивной технологии и нерациональной организации, хозяйством товаропроизводительным. «Прогрессивное развитие земледелия на почве мелкого хозяйства, создаст рынок, опираясь на ко-

\footnotetext{
37 Там же. С. 203.

${ }^{38}$ Струве П.Б. Критические заметки к вопросу об экономическом развитии России. СПб., 1894. С. 112.

39 Струве П.Б. На разные темы (1893-1901 гг.). Сборник статей. СПб., 1902. С. 301.
}

торый будет развиваться русский промышленный капитализм. Рынок этот по мере экономического и общекультурного развития страны и связанного с ним вытеснения натурального хозяйства может неопределённо расти. В этом отношении капитализм в России находится в более благоприятных условиях, чем в других странах» ${ }^{40}$. Обширность российской территории способна стать катализатором этого процесса. При условии строительства путей сообщения и, выражаясь современным языком, современной инфраструктуры, Россия сможет быстрыми темпами развивать и внутренний рынок, и обрабатывающую промышленность. Эти два исходных фактора капитализации всей экономики. Примером тому, считал Струве, может быть опыт развития капитализма в Северной Америке. Правда, «процесс нашего капиталистического развития будет, конечно, в силу нашей экономической и общекультурной отсталости идти медленнее, чем в Америке и носить очень болезненный характер. С этим нужно считаться », предупреждал он ${ }^{41}$.

Естественно, что развитие внутреннего рынка, превращение сельскохозяйственного собственника в товаропроизводителя станет сопровождаться усилением социально-экономического расслоения в деревне, о чём справедливо беспокоились народники. Но это при условии экономического роста меньшее зло по сравнению с «нивелированием» крестьянства на основе всеобщей бедности и нищеты: чем богаче общество, тем больше у него возможностей для социально-правового регулирования экономического расслоения. Думая так Струве, возможно, впадал в немалый утопизм, не предвидя в должной мере всех тех социальных «издержек», которые несёт с собой свободный рынок. (В чём мы убедились на нашем сегодняшнем опыте.). Однако трудно не согласиться с его характеристикой российской ситуации: «техническая нерациональность хозяйства, а не капитализм вот тот враг, который отнимает хлеб насущный у нашего крестьянина. Если капиталистический строй и исполнен противоречий, то из этого вовсе не следует, что капитализм всюду, где он ни существует, виноват во всех бедствиях» ${ }^{2}$.

Технической базой капитализации сельского хозяйства является обрабатывающая промышлен-

\footnotetext{
40 Струве П.Б. Критические заметки к вопросу об экономическом развитии России. СПб., 1894. С. 284.

41 Там же. С. 260-261.

42 Там же. С. 224.
} 


\section{Социальная динамика}

ность. Её развитие - это краеугольный камень предложенной Струве модели экономического роста. Обрабатывающая промышленность играет роль главного фактора расширения границ внутреннего рынка, модернизации сельскохозяйственного производства и социального развития деревни. (Не с этой ли проблемой мы сталкиваемся сегодня?). Рынок превращает земледельца в производителя товара, а развитие обрабатывающей промышленности делает реальной замену натурального хозяйства рациональным хозяйством, основанным на применении передовой техники и научной технологии. Это даёт тот необходимый рост производительности труда, который в свою очередь решает проблему накоплений для осуществления индустриализации. (О наших природных ресурсах - нефти и газе Струве не подозревал, а источники инвестиций в рост промышленности, считал он, надо искать прежде всего у себя, что снова подтвердил наш собственный сегодняшний опыт). «В области обрабатывающей промышленности капитализм в обширном смысле слова неминуемо влечёт за собой рано или поздно капитализм в узком смысле слова: развитие крупного производства)» 43 .

Политика, ориентированная на первоочередное развитие сельскохозяйственного производства, на превращение его в товарное производство, расчистит в России почву для капитализации всего народного хозяйства. Если меры, о которых мечтали народники («право всех на землю», едва ли не с обязательным переделом земли) могут породить, лишь «жалкий сельский пролетариат», то превращение крестьян в товаропроизводителей с одновременным развитием обрабатывающий промышленности, способной «довести» сельскохозяйственный продукт через развитый рынок до потребителя, ведёт к развитию, как бы мы сегодня сказали, агропромышленного комплекса, на базе которого становится возможным социально-экономическое развитие и деревни, и города.

Внедрение меновых отношений в сельском хозяйство при этом не обязательно должно сопровождаться искусственной ломкой исторически укоренившейся в деревне общины: до поры до времени, предостерегал Струве, государство может её сохранить и даже приспособить к новым экономическим условиям, ибо со временем, постепенно, отношения обмена, укрепив позиции

43 Там же. С. 282. самостоятельного производителя, сами всё «расставят по местам». (В этой позиции очевидно просматривается парадигма будущего консервативного либерализма.) И словно оправдываясь за очевидную абсолютизацию роли сельского хозяйства в модернизационных процессах, Струве писал: «Мои личные симпатии вовсе не на стороне экономически крепкого, приспособленного к товарному производству крестьянства, но я не могу не видеть, что политика, которая направится на создание такого крестьянства, будет единственно разумной и прогрессивной политикой, так как она пойдёт на встречу исторически неизбежному прогрессу капиталистического развития, смягчая в то же время его крайности» 44 . (Цель в данном случае оправдывала возможные, т.е. реально применимые, средства её достижения). Конечно, Россия не останется страной исключительно сельскохозяйственной, - это Струве прекрасно понимал. Но начинать капитализацию экономики надо преобразований в сельском хозяйстве, которые в сложившихся условиях (отсутствие в должном объёме промышленного капитала) есть единственный путь к последующему развитию промышленности, к последовательной и масштабной индустриализации. Только таким путём Россия может из бедной капиталистической страны, какой является, превратиться в богатую капиталистическую страну, - был уверен Струве. И этим превращением она дополнит «историческую схему новыми чертами: меновое хозяйство и капитализм в узком смысле слова могут развиваться без сильных средств первоначального накопления, без экспроприации, т.е. без прямого насилия» 45 . Увы, этого не случилось.

Капитализация экономики предполагает усиление роли государства в реализации этого процесса. Струве настаивал на этом условии, что вытекало из его понимания природы государства - скорее либерального, нежели марксистского, акцентирующего классовую природу государственной власти. Не отрицая за государством функции насилия, Струве видел в нём прежде всего продукт культуры. Не принимая революции как метода решения социальных проблем, он возлагал надежды именно на государство - его культурные, социально-экономические и политические функции, отвечающие интересам эволюционного развития общественных структур и форм

\footnotetext{
44 Там же. С. 281

45 Там же. С. 239.
} 


\section{Философия и культура 4(64) • 2013}

жизнедеятельности его граждан. Государство по природе своей - это прежде всего организация порядка; органом насилия оно становится в обществе, в котором подчинение одних групп другими обусловлено его экономической структурой. Этим объясняется тот факт, почему его вмешательство в сферу экономических отношений не может простираться дальше определённых границ. Государство может проводить либо фритредерскую либо протекционистскую политику; может бороться с эксцессами капитализма путём фабричного законодательства, а может открыто защищать интересы капитала; может склоняться в пользу крупного земледелия, а может - в пользу мелкого фермерства, но оно не в состоянии «сделать» то, что может явиться только результатом известного исторического процесса, «оно не может организовать производства на почве совершенно для того неподготовленной» ${ }^{46}$. Иными словами, государственная политика не может выходить за рамки заданной экономическими отношениями целесообразности исторического момента и установленного законопорядка. - В противном случае его действия, направленные на управление процессом, обречены на неуспех. В идеале политика государства должна выражать равнодействующую социальных сил, но практически это, к сожалению, не всегда получается, поскольку часто вмешиваются факторы объективного (экономического) порядка, которые оказываются сильнее его собственных устремлений. Это Струве прекрасно понимал и об этом предупреждал. И тем не менее, он считал, что именно государство призвано снимать возникающие противоречия в обществе и проводить политику с учётом интересов всех его граждан.

Предлагая свою модель капитализации России, Струве не абсолютизировал культурную миссию капиталистической цивилизации, в чём его сразу же после выхода книги стали упрекать и народники, и ортодоксы-марксисты. Он не отрицал, что капитализм не свободен от «некультурных элементов», что он сохраняет эксплуатацию и очевидные искусственные границы человеческой свободы - политической, интеллектуальной и хозяйственно-предпринимательской, а значит - культуры в целом. Отвечая народникам, он, не в оправдание, а в качестве ответа на все нападки в его адрес скажет: «Симпатии к трудящейся народной массе не монополия народников, и мы так же чувствуем глубокое

46 Там же. С. 276. сожаление к разорённому страдальцу-народу. Но картина его разорения лучше всего доказывает нам его культурную беспомощность ${ }^{47}$. И подводя итог всем своим доводам в пользу предложенных способов капитализации России, закончит книгу словами, которые станут программным требованием его будущего «консервативного либерализма»: «нет, признаем нашу некультурность и пойдём на выучку к капитализму» ${ }^{48}$.

\section{4. Чему учиться у капитализма?}

Отвечая своим критикам на этот вопрос, Струве так раскрывал смысл своего призыва: «Я должен с полной определённостью заявить, что инкриминированные слова: «пойдём на выучку к капитализму» вполне соответствуют моему убеждению. Всё дело в смысле «страшных слов». Во-первых, русское общество в его целом потому нуждается в капиталистической выучке, что только эта выучка, развивая производительные силы страны, создаёт и будет создавать условия культурного прогресса и предпосылки новой более высокой экономической формации. Вовторых, только капиталистическая выучка может взрастить классовое самосознание - этот могущественный рычаг общественного развития. B-третьих, только капиталистическая выучка внесёт во взаимные отношения общественных классов полную ясность, которая сделает совершенно невозможной путаницу понятий о роли интеллигенции и государства в экономическом процессе, до самого последнего времени, можно сказать, безраздельно господствующую у нас» 49 . И добавлял: «Это вовсе не значит - для меня по крайней мере, - «будем служить буржуазии», ибо капиталистические отношения подразумевают не одну буржуазию, но и её антипода везде, а тем более у нас, нуждающихся в капиталистической выучке»50. Иными словами, у капитализма следует учиться капитализму. - Его умению рационально организовать хозяйство, творчески использовать достижения мировой цивилизации и прежде всего достижения научно-технического прогресса, умению проводить политику, направ-

\footnotetext{
47 Струве П.Б. Моим критикам // Струве П.Б. На разные темы (1893-1901 гг.). Сборник статей. СПб., 1902. С. 15.

48 Струве П.Б. На разные темы (1893-1901 гг.). Сборник статей. СПб., 1902. С. 300.

49 Струве П.Б. Моим критикам // Там же. С. 15.

50 Там же. С. 16.
} 


\section{Социальная динамика}

ленную на поддержку товаропроизводителя. Капиталистическое ведение хозяйства, организуя массы, «учит их сознательно относиться $\kappa$ условиям своего существования» ${ }^{11}$, 一 и это один из главных уроков капитализма, который следует усвоить. Создавая фактически обобществлённое производство, капитализм развивает в массах способность к коллективным действиям, подготавливает их к участию в историческом движении общества. В условиях капитализма массы проходят своеобразную школу социального коллективного поведения на основе усвоенных прав и обязанностей, формирующих у них необходимый уровень правосознания, потребность в демократических нормах общежития. Струве был уверен: «Внешние условия, в которые современный капитализм ставит трудящиеся массы, развивает в них чувство активности, политический смысл, способность к коллективному действию и тем самым подготавливают их к той роли, которую им по объективному ходу материального процесса суждено играть в эволюции капиталистического строя ${ }^{52}$.

Призывая идти на выучку к капитализму, Струве был далёк от апологетики последнего как образа жизни, говорил, что не является его адептом и не идеализирует его как общественный строй. Но нельзя, считал он, оставаясь на позициях современного научного знания, исходить из моральной парадигмы в оценке истории. «Капитализм как эксплуатация человека человеком, есть зло с точки зрения наших идеалов. И если мы будем смотреть на него только с этой точки зрения, то мы придём прямым путём к простому выводу: не надо капитализма! Раз этот вывод подчинит себе наше мышление, нам трудно будет приблизиться к пониманию объективного процесса: капитализм <..> в наших глазах явится тогда чем-то только вроде, если можно так выразиться, «злоумышления». Но капитализм, как и всё, имеет своё достаточное основание, для понимания которого таких категорий, как добро и зло, недостаточно. С этой точки зрения взглянули мы на вопрос об экономическом развитии
России. Капитализм разрушает так называемые «устои», но это удаётся ему только потому, что «устои» никуда негодны и сами разваливаются. <..> Таким образом, капитализм не только зло, но и могущественный фактор культурного процесса, - фактор, не только разрушающий, но и созидающий. Это прекрасно понимали и понимают на Западе те, кто во имя идеалов социальной справедливости выступили на борьбу с капитализмом», - писал Струве не без упрёка в адрес отечественных социал-демократов ${ }^{53}$.

Придерживаясь материалистического толкования истории, Струве, видел историческую миссию капитализма в создании материальных и культурных условий для дальнейшего прогресса и потому был далёк от мысли рассматривать капитализм в качестве «вечной» формации. Достигая вершин товарного производства, капитализм создаёт обобществленное производство и уже поэтому, считал он в момент написания книги, «не может мириться с беспорядочным, чисто индивидуалистическим распределением и потреблением: таким образом, капитализм объективно выдвигает народно-хозяйственные принципы, отрицающие его частнохозяйственную основу»54. Этому тоже следует учиться у капитализма - его умению предвидеть начало зарождающихся тенденций в экономике и вовремя открывать социальные шлюзы для их благоприятного (с точки зрения интересов системы) развития (Сегодня мы можем сказать, что это далеко не всегда удаётся делать и капитализму).

Рассматривая возможность исторического преодоления капитализма другой организацией хозяйства, Струве, признавался, что «склонен задать еретический вопрос: будет ли «крушение» капиталистического общества в действительности означать победу социализма?»55. На еретический вопрос Струве история дала свой ответ. И, главное, она подтвердила истинность предложенной им модели модернизации страны, обеспечивающей ей 1) движение по общему для всех народов пути цивилизованного развития и 2) сохранение собственное национальное достоинство.

\footnotetext{
${ }^{51}$ Струве П.Б. Критические заметки к вопросу об экономическом развитии России. СПб., 1894. С. 160.

52 Там же. С. 283.
}

\footnotetext{
53 Там же. С. 288.

54 Там же. С. 287.

55 Струве П.Б. Марксовская теория социального развития // Образ будущего в социально-экономической мысли конца XIX начало ХХ века. Избранные произведения. М., 1994. С. 148.
} 


\section{Философия и культура 4(64) • 2013}

\section{Список литературъ:}

1. Ангарский Н. Легальный марксизм. Краткий очерк. Вып. 1 (1876-1897). М., 1930.

2. Бердяев Н.А. Субъективизм и индивидуализм в общественной философии. СПб, 1901.

3. Булгаков С.Н. От марксизма к идеализму. Сборник статей (1896-1903). СПб., 1904.

4. Гайденко П.П. Под знаком меры // Вопросы философии. 1992. № 2.

5. Гнатюк О.Л. П.Б. Струве как социальный мыслитель. СПб., 1996.

6. Консерватизм и либерализм: созвучии и диссонансы. Материалы международной конференции к 125-летию со дня рождения П.Б. Струве. Пермь, 1996.

7. Кантор К.М. Немецкая идеология Маркса-Энгельса и русский марксизм // Вопросы философии. 1995. № 12.

8. Ленин В.И. Экономическое содержание народничества и критика его в книге г. Струве // Ленин В.И. Полное собрание сочинений. 5-е изд. Т. 1. М., 1967.

9. Пайпс Р. Теория капиталистического развития П.Б. Струве. М., 2012.

10. Плеханов Г.В. Критика наших критиков. Г-н Струве в роли критика марксовой теории общественного развития // Плеханов Г.В. Избранные философские произведения: в 5 т. М., 1956. Т. 2.

11. Проблемы идеализма. Сборник статей / Под ред. П.И. Новгородцева. М., 1902.

12. Смирнов И.П. От марксизма к идеализму (М.И. Туган-Барановский, С.Н. Булгаков, Н.А. Бердяев). M., 1995.

13. Струве П.Б. Критические заметки к вопросу об экономическом развитии России. Вып. 1. СПб., 1984.

14. Струве П.Б. На разные темы (1893-1901). Сборник статей. СПб, 1902.

15. Струве П.Б. PATRIOTICA. Политика, культура, религия, социализм. М., 1997.

16. Струве П.Б. Мои встречи и столкновения с Лениным // Русская идея в кругу писателей и мыслителей русского зарубежья: в 2-х т. Т. 1. М., 1994.

17. Струве П.Б. Марксовская теория социального развития // Образ будущего в русской социально-экономической мысли конца XIX - начала XX века. Избранные произведения. М., 1994.

\section{References (transliteration):}

1. Angarskiy N. Legal'nyy marksizm. Kratkiy ocherk. Vyp. 1 (1876-1897). M., 1930.

2. Berdyaev N.A. Sub'ektivizm i individualizm v obshchestvennoy filosofii. SPb, 1901.

3. Bulgakov S.N. Ot marksizma k idealizmu. Sbornik statey (1896-1903). SPb, 1904.

4. Gaydenko P.P. Pod znakom mery // Voprosy filosofii. 1992. № 2.

5. Gnatyuk O.L. P.B. Struve kak sotsial'nyy myslitel'. SPb, 1996.

6. Konservatizm i liberalizm: sozvuchii i dissonansy. Materialy mezhdunarodnoy konferentsii k 125-letiyu so dnya rozhdeniya P.B. Struve. Perm', 1996.

7. Kantor K.M. Nemetskaya ideologiya Marksa-Engel'sa i russkiy marksizm // Voprosy filosofii. 1995. № 12.

8. Lenin V.I. Ekonomicheskoe soderzhanie narodnichestva i kritika ego v knige g. Struve // Lenin V.I. Polnoe sobranie sochineniy. 5-e izd. T. 1. M., 1967.

9. Payps R. Teoriya kapitalisticheskogo razvitiya P.B. Struve. M., 2012.

10. Plekhanov G.V. Kritika nashikh kritikov. G-n Struve v roli kritika marksovoy teorii obshchestvennogo razvitiya // Plekhanov G.V. Izbrannye filosofskie proizvedeniya. V 5-ti t. M., 1956. T. 2.

11. Problemy idealizma. Sbornik statey / Pod red. P.I. Novgorodtseva. M., 1902.

12. Smirnov I.P. Ot marksizma k idealizmu (M.I. Tugan-Baranovskiy, S.N. Bulgakov, N.A. Berdyaev). M., 1995.

13. Struve P.B. Kriticheskie zametki k voprosu ob ekonomicheskom razvitii Rossii. Vyp. 1. SPb, 1984.

14. Struve P.B. Na raznye temy (1893-1901). Sbornik statey. SPb, 1902.

15. Struve P.B. PATRIOTICA. Politika, kul'tura, religiya, sotsializm. M., 1997.

16. Struve P.B. Moi vstrechi i stolknoveniya s Leninym // Russkaya ideya v krugu pisateley i mysliteley russkogo zarubezh'ya: v 2-kh t. T. 1. M., 1994.

17. Struve P.B. Marksovskaya teoriya sotsial'nogo razvitiya // Obraz budushchego v russkoy sotsial'no-ekonomicheskoy mysli kontsa XIX - nachala KhKh veka. Izbrannye proizvedeniya. M., 1994. 